\title{
PENGETAHUAN TENTANG MEROKOK TERHADAP PERILAKU MEROKOK PADA SISWA DI SMKN 6 KOTA PEKANBARU
}

\author{
Tyagita Widya Sari ${ }^{1 *}$, Muliana Lestari², Nadia Rukmana ${ }^{3}$, Ningrum4, \\ Yogi Ersandy ${ }^{5}$ \\ ${ }^{1}$ Departemen Ilmu Kesehatan Masyarakat, Universitas Abdurrab, Pekanbaru, Riau,

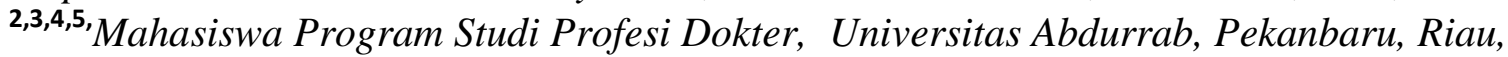 \\ Email:tyagita.ws@univrab.ac.id
}

\begin{abstract}
Background: The World Health Organization (WHO) states that smoking causes fatal health problems which cause about 8 million deaths per year worldwide. The risk of death from active smokers is higher than passive smokers, which is about more than 7 million deaths occur in active smokers and 1.2 million deaths occur in passive smokers. The results of the 2018 Basic Health Research report (Riskesdas) showed that the prevalence of smoking among adolescents of school age or aged 10-18 years (both inside and outside school) had increased according to the 2018 Basic Health Research (Riskesdas) which was recorded at $9.1 \%$, up from Riskesdas 2013 which was 7.2\%. Lack of knowledge about smoking will cause teens to be easily influenced by peers. Good knowledge illustrates a broader experience regarding smoking so that it will also affect one's smoking behavior Objectives: To determine the correlation of knowledge about smoking with smoking behavior of students at SMKN 6 Pekanbaru City. Methods: This study used an observational study with a cross-sectional study design. The sampling technique in this study was simple random sampling, where the number of respondents in this research was 149 students.

Results: Knowledge about smoking is correlated to smoking behavior of students with a p-value of 0.048 ( $p$-value <0.05) and a weak correlation power with a negative direction $(r=-0,162)$. Conclusion: Knowledge about smoking is correlated to smoking behavior of students at SMKN 6 Pekanbaru City. The lower the students' knowledge about smoking, the worse their smoking behavior will be.
\end{abstract}

Keywords: Smoking, Knowledge, Behavior, Students, Pekanbaru

\begin{abstract}
ABSTRAK
Latar Belakang: World Health Organization (WHO) menyatakan bahwa rokok menyebabkan masalah kesehatan yang fatal dan menjadi penyebab kematian kurang lebih 8 juta orang per tahun di seluruh dunia. Risiko kematian akibat perokok aktif lebih tinggi daripada perokok pasif yaitu sekitar lebih dari 7 juta kematian terjadi pada perokok aktif dan 1,2 juta kematian terjadi pada perokok pasif. Hasil dari laporan Riset Kesehatan Dasar (Riskesdas) 2018 menunjukkan bahwa prevalensi merokok di kalangan remaja usia sekolah atau berusia 10-18 tahun (baik di dalam maupun di luar sekolah) mengalami kenaikan menurut Riset Kesehatan Dasar (Riskesdas) 2018 yaitu tercatat sebesar 9,1\%, meningkat dari Riskesdas 2013 yakni 7,2\%. Pengetahuan yang kurang tentang merokok akan menyebabkan remaja mudah terpengaruh dengan teman sebaya. Pengetahuan yang baik menggambarkan pengalaman yang lebih luas mengenai rokok sehingga juga akan mempengaruhi perilaku merokok seseorang Tujuan Penelitian : Untuk mengetahui hubungan pengetahuan tentang merokok dengan perilaku merokok pada siswa di SMKN 6 Kota Pekanbaru. Metode Penelitian: Penelitian ini menggunakan penelitian observasional dengan desain studi cross-sectional (potong lintang). Teknik pengambilan sampel dalam penelitian ini adalah simple random sampling, dimana jumlah responden dalam penelitan ini adalah 149 siswa. Hasil Penelitian : Pengetahuan tentang merokok berhubungan dengan perilaku merokok pada siswa dengan $p$ value 0,048 ( $p$-value $<0,05)$ dan kekuatan korelasi yang lemah dengan arah negatif $(\mathrm{r}=-0,162)$. Kesimpulan : Pengetahuan tentang merokok berhubungan dengan perilaku merokok pada siswa di SMKN
\end{abstract}


6 Kota Pekanbaru. Semakin rendah pengetahuan siswa tentang merokok, maka perilaku merokok siswa juga semakin buruk.

Kata Kunci : Merokok, Pekanbaru, Pengetahuan, Perilaku, Siswa

\section{PENDAHULUAN}

Merokok merupakan salah satu
perilaku yang menyebabkan masalah
kesehatan terbesar di dunia. Perilaku merokok menyebabkan masalah kesehatan yang fatal dan menjadi penyebab kematian sekitar 8 juta orang per tahun di seluruh dunia. Risiko kematian akibat perokok aktif lebih tinggi daripada perokok pasif, di mana sekitar 7 juta kematian terjadi pada perokok aktif dan 1,2 juta kematian terjadi pada perokok pasif (World Health Organization, 2019).

Indonesia merupakan salah satu negara dengan tingkat prevalensi perokok yang tertinggi di dunia. Pada tahun 2011, sekitar $30 \%$ individu yang berusia 15 tahun ke atas merokok setiap hari (Kusumawardani, Tarigan, Suparmi, \& Schlotheuber, 2018). Berdasarkan Global Youth Tobacco Survey (GYTS) tahun 2014 di Indonesia, survei siswa berbasis sekolah yang representatif secara nasional melaporkan prevalensi perokok aktif saat ini sekitar 18,3\% yaitu pada kelompok usia 1315 tahun, dan yang terpapar asap rokok di rumah sebesar 57,3\%. Berdasarkan survei yang dilakukan didapatkan hasil anak lakilaki yang merokok adalah sebesar 33,9\% dan anak perempuan 2,5\% (World Health Organization, 2015). Prevalensi merokok di kalangan remaja usia sekolah atau berusia 10-18 tahun, baik di dalam maupun di luar sekolah, mengalami peningkatan menurut Riset Kesehatan Dasar (Riskesdas) 2018 yaitu sebesar $9,1 \%$, di mana jumlah ini meningkat dari Riskesdas 2013 yakni 7,2\% (Kementerian Kesehatan Republik Indonesia, 2019).

Kebiasaan merokok pada anak usia sekolah di Indonesia sering tampak pada siswa SMA, karena usia ini merupakan masa peralihan antara masa kanak-kanak menuju dewasa. Masa remaja termasuk masa yang sangat penting dan menentukan, karena pada masa ini anak-anak mengalami banyak perubahan pada aspek psikis dan fisik. Terjadinya perubahan kejiwaan menimbulkan kebingungan di kalangan remaja, sehingga mereka mengalami penuh gejolak emosi dan tekanan jiwa. Hal ini dapat menyebabkan remaja mudah menyimpang dari aturan dan norma-norma sosial yang berlaku di kalangan masyarakat. Hasil penelitian terdahulu menunjukkan bahwa sebagian besar remaja yang merokok memiliki pengetahuan tentang merokok yang kurang $(52,6 \%)$ dibandingkan yang memiliki pengetahuan tentang merokok baik $(47,4 \%)$ di Kampung Bojong Rawalele Kota Bekasi pada tahun 2017 (Maseda, Suba, \& Wongkar, 2013).

Berdasarkan survei pendahuluan yang telah dilakukan pada awal Bulan Agustus 2019 di SMKN 6 Kota Pekanbaru, beberapa siswa memiliki perilaku merokok akibat pergaulan dan kurangnya pengetahuan tentang bahaya merokok. Selain itu, belum pernah dilakukan penyuluhan tentang merokok dan bahayanya oleh petugas kesehatan di sekolah ini.

Berdasarkan latar belakang masalah yang telah dipaparkan, maka peneliti merumuskan masalah apakah ada hubungan antara pengetahuan tentang merokok dengan perilaku merokok pada siswa SMKN 6 Kota Pekanbaru. Tujuan penelitian ini adalah mengetahui hubungan antara pengetahuan tentang merokok dengan perilaku merokok pada siswa SMKN 6 Kota Pekanbaru.

\section{METODE PENELITIAN}


Penelitian ini merupakan penelitian observasional dengan desain studi crosssectional (potong lintang). Penelitian ini telah dilakukan selama 1 hari pada tanggal 27 Agustus 2019 di SMKN 6 Kota Pekanbaru. Variabel independen pada penelitian ini adalah pengetahuan tentang merokok siswa, sedangkan variabel dependennya adalah perilaku merokok siswa.

Populasi penelitian yaitu seluruh siswa kelas XI berjumlah sebanyak 237 responden. Pemilihan kelas XI menjadi sampel adalah dengan pertimbangan bahwa siswa kelas XII sedang magang, dan data siswa kelas $\mathrm{X}$ belum lengkap. Populasi yang terdapat dalam penelitian ini berjumlah 237 orang dan presisi yang ditetapkan 0,05, maka besar sampel pada penelitian ini yang dihitung menggunakan Rumus Slovin berjumlah 149 responden. Teknik pengambilan sampel pada penelitian ini dilakukan secara simple random sampling yang diambil secara acak dari anggota populasi dengan menggunakan aplikasi random sample generator.

Kriteria inklusi sampel pada penelitian ini antara lain siswa yang berjenis kelamin laki-laki, berusia 15-19 tahun, hadir saat penelitian dilakukan, dan bersedia menjadi responden dengan menandatangani lembar informed consent. Sedangkan, kriteria eksklusi adalah siswa yang berusia kurang dari 15 tahun dan lebih dari 19 tahun. Sebelum pengisian kuesioner, peneliti memberikan penjelasan mengenai tata cara pengisian kuesioner kepada responden. Selama pengisian kuesioner, responden didampingi oleh peneliti.

Alat ukur yang digunakan dalam penelitian ini adalah kuesioner untuk menilai pengetahuan tentang merokok dan perilaku merokok pada siswa. Kuesioner pengetahuan merokok terdiri dari 12 pertanyaan dengan dua pilihan jawaban yaitu benar dan salah. Apabila responden menjawab pertanyaan dengan benar sesuai kunci jawaban maka akan diberi skor 1, apabila tidak sesuai maka diberi skor 0 . Rentang skor minimal dan maksimal kuesioner pengetahuan tentang merokok adalah 0-12. Kuesioner perilaku merokok terdiri dari 19 pertanyaan dngan beberapa pilihan jawaban yaitu selalu, sering, kadangkadang dan tidak pernah. Apabila responden menjawab selalu maka diberi skor 3, sering diberi skor 2, kadang-kadang diberi skor 1, dan tidak pernah diberi skor 0 . Kuesioner yang digunakan dalam penelitian ini adalah modifikasi kuesioner dari (Syarfa, 2015) dan telah diuji validitas dan reliabilitas terlebih dahulu. Analisis data pada penelitian ini dilakukan secara univariat untuk menghasilkan tabel distribusi frekuensi atau persentase. Selanjutnya, dilakukan analisis bivariat menggunakan uji korelasi Pearson Product Moment atau Spearman Rank, di mana akan menghasilkan nilai signifikansi $p$-value dan koefisien korelasi (r).

\section{HASIL DAN PEMBAHASAN}

\section{Uji Normalitas Data}

Tabel 1. Hasil Uji Normalitas Data

\begin{tabular}{ccc}
\hline Variabel & p-value & Keterangan \\
\hline $\begin{array}{c}\text { Pengetahuan } \\
\text { tentang } \\
\text { Merokok }\end{array}$ & 0,000 & $\begin{array}{c}\text { Distribusi tidak } \\
\text { normal } \\
(p \text {-value }<0,05)\end{array}$ \\
\hline $\begin{array}{c}\text { Perilaku } \\
\text { Merokok }\end{array}$ & 0,000 & $\begin{array}{c}\text { Distribusi tidak } \\
\text { normal } \\
(p \text {-value }<0,05)\end{array}$ \\
\hline
\end{tabular}

Uji normalitas data dilakukan dengan uji Kolmogorov Smirnov karena besar sampel > 50 responden. Hasil uji normalitas dari kedua variabel yang diuji menunjukkan bahwa data terdistribusi tidak normal, sehingga digunakan uji korelasi Spearman Rank.

\section{Tabulasi Silang Variabel Independen dan Dependen}


Tabel 2. Tabel Silang Pengetahuan Tentang Merokok Dengan Perilaku Merokok

\begin{tabular}{|c|c|c|c|c|}
\hline \multirow{2}{*}{$\begin{array}{c}\text { Pengetahuan } \\
\text { Tentang } \\
\text { Merokok }\end{array}$} & \multicolumn{3}{|c|}{ Perilaku Merokok } & \multirow[t]{2}{*}{ Total } \\
\hline & Baik & Sedang & Buruk & \\
\hline Tinggi & 111 & 20 & 3 & 134 \\
\hline Sedang & 10 & 4 & 0 & 14 \\
\hline Rendah & 1 & 0 & 0 & 1 \\
\hline Total & 122 & 24 & 3 & 149 \\
\hline
\end{tabular}

Untuk kepentingan analisis bivariat, maka variabel pengetahuan tentang merokok dan dikategorikan menjadi tinggi, sedang, dan rendah. Variabel perilaku merokok dikategorikan menjadi baik, sedang, dan buruk. Sebagian besar responden memiliki perilaku merokok yang berada pada kategori baik yaitu sebanyak 122 dari 149 responden $(81,9 \%)$, sedangkan sebagian besar responden memiliki pengetahuan tentang merokok yang berada pada kategori tinggi yaitu sebanyak 134 dari 149 responden $(89,9 \%)$.

Proporsi responden dengan perilaku merokok baik sebanyak 122 responden, di mana sebagian besar responden berada pada kategori pengetahuan tentang merokok yang tinggi yaitu sebanyak 111 responden (91\%). Proporsi responden dengan perilaku merokok sedang sebanyak 24 responden, di mana sebagian besar responden berada pada kategori pengetahuan tentang merokok yang tinggi yaitu sebanyak 20 responden $(83,3 \%)$. Proporsi responden dengan perilaku merokok buruk sebanyak 3 responden, di mana keseluruhan responden berada pada kategori pengetahuan tentang merokok yang tinggi yaitu sebanyak 3 responden $(100 \%)$.

\section{Uji Korelasi Spearman}

Tabel 3. Hubungan Pengetahuan Tentang Merokok Dengan Perilaku Merokok Pada Siswa SMKN 6 Kota Pekanbaru

\begin{tabular}{ccc}
\hline Variabel & \multicolumn{2}{c}{$\begin{array}{c}\text { Perilaku merokok } \\
\text { siswa }\end{array}$} \\
\hline Pengetahuan & $\mathrm{N}$ & 149 \\
\cline { 2 - 3 } siswa & $p$ - & 0,048 \\
tentang & \multicolumn{2}{c}{ value } \\
merokok & $\mathrm{r}$ & $-0,162$ \\
\hline
\end{tabular}

Berdasarkan Tabel 3 dapat diketahui bahwa dari 149 sampel penelitian diperoleh $p$-value sebesar 0,048 ( $p$-value $<0,05)$, sehingga dapat dinyatakan bahwa terdapat hubungan antara pengetahuan tentang merokok dengan perilaku merokok. Selanjutnya, diketahui angka koefisien korelasi (r) sebesar -0,162, sehingga dapat dinyatakan bahwa hubungan antar kedua variabel lemah dengan arah korelasi negatif. Jadi, dapat disimpulkan bahwa semakin rendah pengetahuan siswa tentang merokok maka perilaku merokok siswa juga semakin buruk.

Menurut Lawrence Green, salah satu faktor yang menentukan perilaku seseorang yaitu faktor predisposisi, diantaranya adalah pengetahuan. Pengetahuan adalah hasil penginderaan manusia atau hasil tahu seseorang terhadap objek melalui indera yang dimilikinya. Pengetahuan merupakan domain yang sangat penting bagi terbentuknya perilaku seseorang yaitu perilaku yang tampak (overt behavior). Apabila suatu tindakan didasari oleh pengetahuan, maka tindakan tersebut akan bersifat langgeng (long lasting). Sebaliknya, jika perilaku tersebut tidak didasari oleh pengetahuan dan kesadaran, maka perilaku tersebut tidak bertahan lama (Notoatmodjo, 2014). Salah satu pendorong perilaku merokok adalah pengetahuan, di mana seorang remaja yang telah memahami mengenai 
merokok dan bahayanya akan berkeyakinan kuat untuk menghindari rokok (Wijayanti, Dewi, \& Rifqatussa'adah, 2017).

Hal ini sesuai dengan penelitian terdahulu yang menyatakan bahwa terdapat hubungan antara pengetahuan tentang bahaya merokok dengan perilaku merokok pada remaja putra di SMA Negeri I Tompasobaru Kabupaten Minahasa Selatan pada tahun 2013 ( $p$ value $=0,015)$ (Maseda et al., 2013). Pada penelitian ini, siswa yang memiliki pengetahuan baik $(85,9 \%)$ tentang bahaya merokok lebih banyak dibandingkan siswa yang memiliki pengetahuan kurang baik $(14,1 \%)$ tentang bahaya merokok. Mereka tidak akan mudah terpengaruh terhadap perilaku merokok, jika mereka memiliki pengetahuan yang baik terhadap bahaya merokok tersebut.

Hasil penelitian lainnya juga menyatakan bahwa terdapat hubungan yang signifikan antara pengetahuan tentang rokok dengan perilaku merokok pada siswa kelas $\mathrm{X}$ dan XI SMKN 5 Kota Pekanbaru pada tahun 2016 ( $p$ value $=0,005)$ (Alamsyah \& Nopianto, 2017). Hasil penelitian ini menunjukkan bahwa pengetahuan merupakan modal dasar bagi seseorang untuk berperilaku. Pengetahuan yang cukup akan memotivasi individu untuk berperilaku baik. Orang yang dipenuhi banyak pengetahuan akan mempersepsikan informasi tersebut sesuai dengan predisposisi psikologisnya. Pengetahuan yang tinggi tentang rokok pada remaja cenderung memperkecil kemungkinan remaja tersebut berperilaku merokok. Hal ini disebabkan remaja tersebut telah mengetahui bahaya atau dampak negatif yang ditimbulkan oleh rokok.

\section{SIMPULAN}

Berdasarkan hasil penelitian yang telah dilakukan pada siswa di SMKN 6 Kota Pekanbaru, maka diperoleh simpulan penelitian sebagai berikut :

1. Sebagian besar responden memiliki pengetahuan tentang merokok tinggi yaitu sebanyak 134 dari 149 orang $(89,9 \%)$.

2. Sebagian besar responden memiliki perilaku merokok baik yaitu sebanyak 122 dari 149 orang $(81,9 \%)$.

3. Terdapat hubungan antara pengetahuan tentang merokok dengan perilaku merokok pada siswa SMKN 6 Kota Pekanbaru dengan kekuatan korelasi lemah dengan arah korelasi negatif ( $p$ value $=0,048 ; r=-0,162$ ).

\section{DAFTAR PUSTAKA}

Alamsyah, A., \& Nopianto. (2017). Determinan Perilaku Merokok Pada Remaja. Jurnal Endurance, 2(1), 25. https://doi.org/10.22216/jen.v2i1.1372

Kementerian Kesehatan Republik Indonesia. (2019). Laporan Nasional Riset Kesehatan Dasar 2018. Jakarta. Retrieved from http://labmandat.litbang.depkes.go.id/i mages/download/laporan/RKD/2018/L aporan_Nasional_RKD2018_FINAL.p df

Kusumawardani, N., Tarigan, I., Suparmi, \& Schlotheuber, A. (2018). Socioeconomic, demographic and geographic correlates of cigarette smoking among Indonesian adolescents: results from the 2013 Indonesian Basic Health Research (RISKESDAS) survey. Global Health Action, 11(1). https://doi.org/https://dx.doi.org/10.108 0\%2F16549716.2018.1467605

Maseda, D. R., Suba, B., \& Wongkar, D. 
(2013). Hubungan Pengetahuan Dan Sikap Tentang Bahaya Merokok Dengan Perilaku Merokok Pada Remaja Putra Di Sma Negeri I Tompasobaru. Jurnal Keperawatan, l(1), 1-8. Retrieved from https://ejournal.unsrat.ac.id/index.php/j $\mathrm{kp} /$ article/view/2176/1734

Notoatmodjo, S. (2014). Ilmu Perilaku Kesehatan. Jakarta: Rineka Cipta.

Syarfa, I. (2015). Gambaran Tingkat Pengetahuan, Perilaku Merokok, dan Nikotin Dependen Mahasiswa UIN Syarif Hidayatullah Jakarta. UIN Syarif Hidayatullah.

Wijayanti, E., Dewi, C., \& Rifqatussa'adah, R. (2017). Faktor-faktor yang
Berhubungan dengan Perilaku Merokok pada Remaja Kampung Bojong Rawalele, Jatimakmur, Bekasi. Global Medical \& Health Communication (GMHC), 5(3), 194198.

https://doi.org/10.29313/gmhc.v5i3.229 8

World Health Organization. (2015). Global Youth Tobacco Survey (GYTS). Retrieved from https://www.apps.who.int/tobacco/docu ments/ino_report_2014.pdf

World Health Organization. (2019). Tobacco Data. Retrieved from https://www.who.int/news-room/factsheets/detail/tobacco 